\title{
坪根式バイトゲージの特徴と使用法について
}

\author{
九州橉科大学第 1 補経学教室（主任：豊田静夫教授) \\ 三宅茂 樹・豊田静 夫・堀孝良 \\ 尔川雅 雄・北村加扔り・佐 藤 博 信 \\ 清 水 稔 弘・安東 駿 輔
}

昭和55年 1 月 23 日受付

(本論文の要旨は昭和51年 5 月23日, 第36回九州歯科学会総会および昭和 55 年 1 月 23 日, 九州歯 科学会 1 月例会に扔いて発表した〉

\section{The Characteristics and Usage of the Tsubone's Bite Gauge}

Shigeki Miyake, Shizuo Toyoda, Takayoshi Hori, Masao Morikawa, Kaori Kitamura, Hironobu Sato,

Toshihiro Shimizu and Shunsuke Ando

First Department of Prosthetic Dentistry (Chief : Prof. Shizuo Toyoda)

Kyushu Dental College, Kitakyushu, Japan

Determination and confirmation of vertical jaw relation (vertical dimension) at the time of full denture construction prosthesis is one of the most difficult steps. As a device for recording vertical jaw relation, the Tsubone's bite gauge has been in use at our clinic and good results have been obtained.

The characteristics and usage of the Tsubone's bite gauge have been described in the present paper and examination has been made of the vertical jaw distance of individual normal occlusion and the measurement taken of the parts, deemed to be related, of the body.

The examination indicated that the measurements were approximately the same for subnasal point-submental region distance at mandibular rest position, pupil line-oral fissure distance, and the left index finger length.

The measurements did not vary much when they were taken by one and the same operator.

The measurements however varied among different operators. Therefore, care must be taken on this respect in using the Tsubone's bite gauge.

\section{緒 言}

天然䍘を失った無菌顎者に対して，適切な垂直的（上 下的）および水丰的（左右的）顎関係を与えることは総 義雪製作過程のうち最も困難なステップのひとつであ
る.乙のうち水平的䫛関係の決定については，パントグ ラフ法, ゴシックアーチ法などある程度科学的に認めら れている方法があるが，垂直的頻関係（咬合の高さ）の 決定については生理学的, 審美的要素などと密接な関係 があるにもかかわらず，その確固たる方法がなく，術者 
の知識や経験に負うととろが大である。

そこで現在臨休で行われている垂直的顎関係の決定法 の主なもの分類してみると，以下のようになる。

1) 生理学的機能を応用する方法

i ）生理的安静位を利用する方法 ${ }^{1-4}$ )

ii）発音機能を利用する方法 ${ }^{5-61}$

iii）與下運動を利用する方法7

iv）咬合力を利用する方法8-91

v) 筋電図を利用する方法 101

vi）マイオモ二タ一を利用する方法 ${ }^{11}$

vii）患者の筋感覚を利用する方法 12-14)

2) 解剖学的, 形態学的および人類学的方法

i ) 点描間計測法 ${ }^{6}$

ii）顔面計測法 ${ }^{15-25)}$

3) 側貌紙型党利用する方法 26 - 27)

4) 透明レジンマスクを利用する方法 ${ }^{28)}$

5) X線在利用する方法 ${ }^{29-33}$

これらは垂直的頭関係の記録に際して，すべて単独で 用いられるものではなく，いくつかの方法を併用するこ とにより総合的に決定されているのであるが，その垂臬 的な高さを計測する手段が必要であり，数值として表示 されるととが望ましい，とのため測定器のひとつとし て，ノギスやバイトゲージが臨床で広く利用されてい る。

バイトゲージとして古くはWillis , F.M. (1930)15，! 6)のバイトゲージ, Sorenson $(1934)^{19)}$ の dentofacial scale, Bruno, A. $(1954)^{20}$ のバイトゲージ，本邦で は坪根 (1958) 22-24) の坪根式バイトゲージ，堀江(1973)

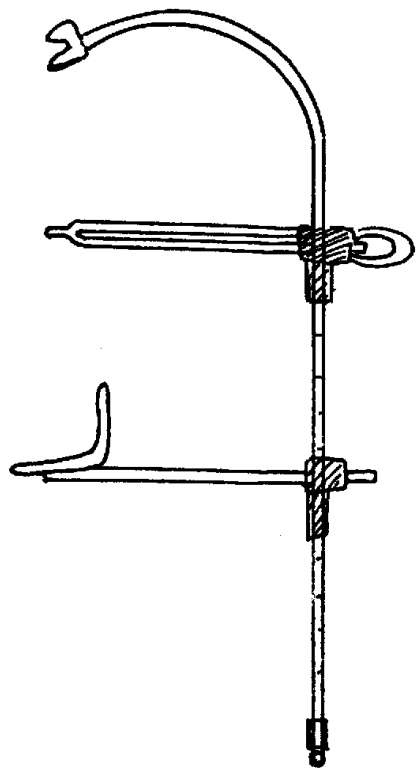

図 1 Sorenson $の$ dentofacial scale
25)の堀江式バイトゲージなどが開発されてきた（図1 $\sim 5$ ).

これらのうち坪根式バィトゲージは日本人の顔貌に適 合しやすいように1958年坪根により開発されたもので, 我々は日常の臨床にこのバイトゲージを使用し，良好な 結果を得ている. そ乙で今回坪根式バイトゲージの特 徵，使用法およゔ変遷を紹介する．またこの坪根式バイ

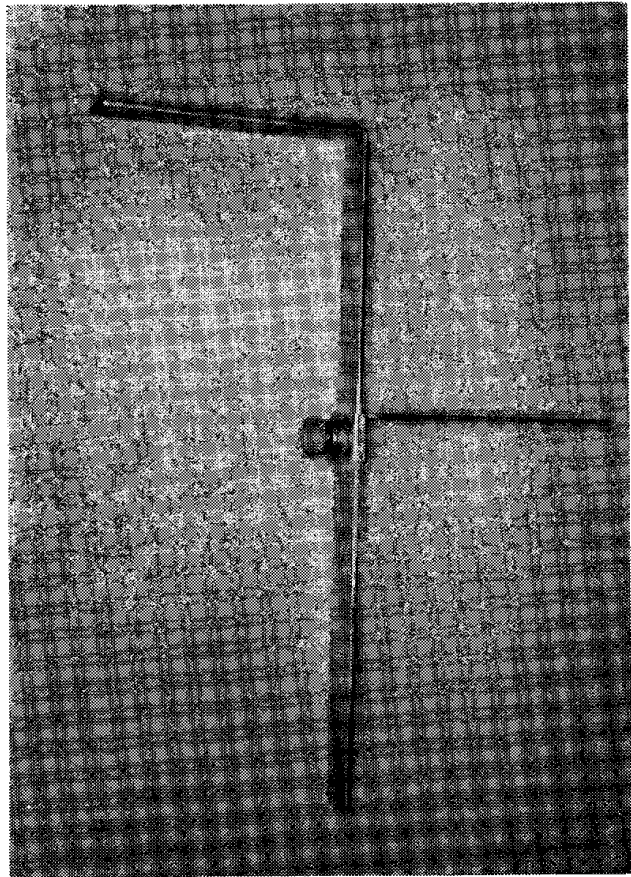

図 2 Willis のバイトゲージ

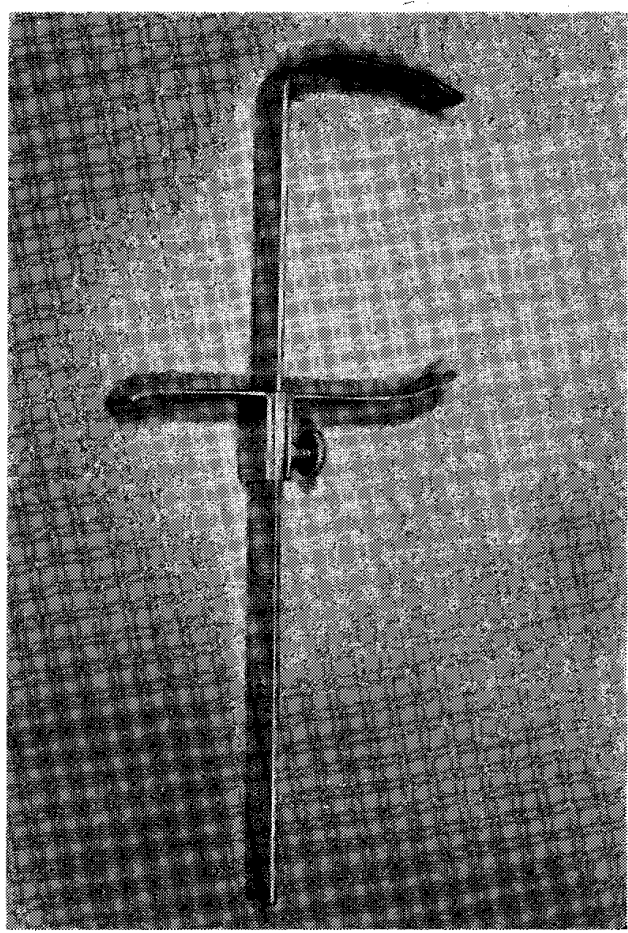

应 3 Bruno のバイトゲージ 


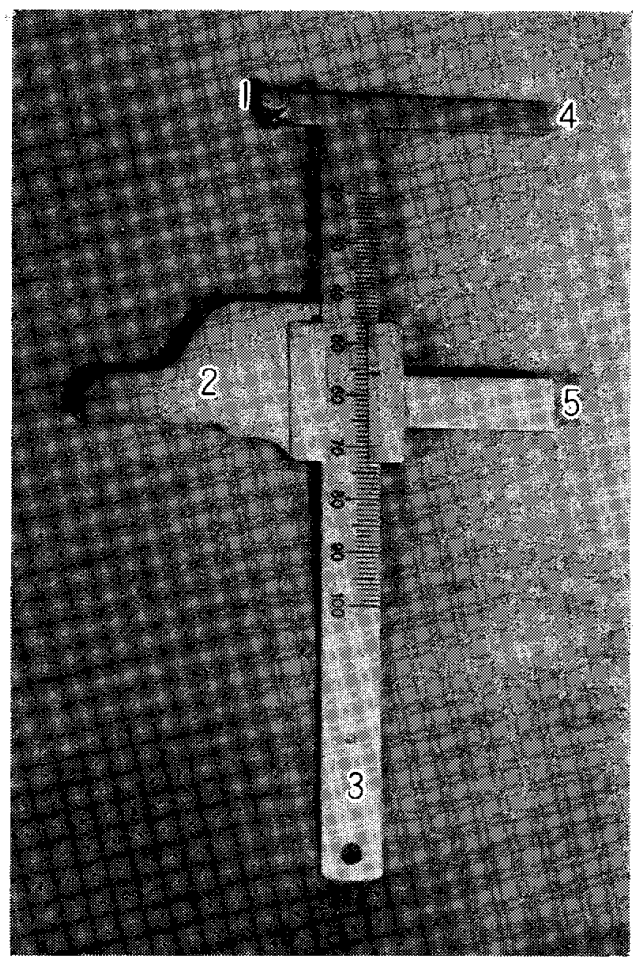

図 4 坪根式バイトゲージ

1. 鼻下点指示桿

2. オトガイ成指示桿

3. 重直桿

4. 瞳孔線指示桿

5. 上下曰唇接合線指示桿

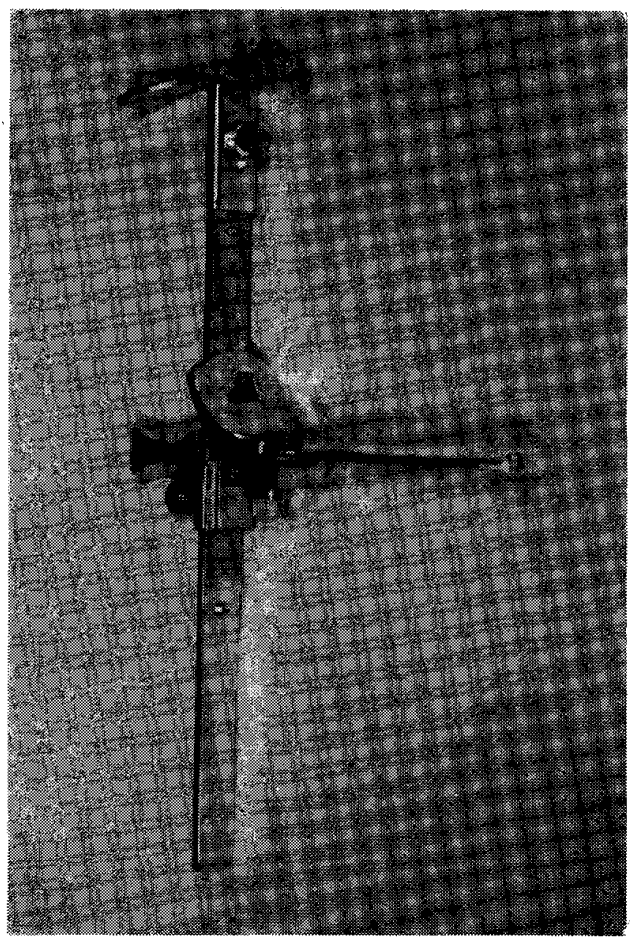

应 5 堀江式バイトゲージ
トゲーシは鼻下点ーオトガイ底間距離を計測する目的で 開発されたものであるが, 盲下点一オトガイ底間距離と 関係があると報告されている身体および顔面各部につい ても成人有雨顎者を対象として計測を行ったので，その 結果についても報告する。

\section{坪根式バイトゲージの特徴, 使用法および その变瀜}

坪根式バイトゲージ Willis，F.M.のバイトゲー ジをとに，1958年坪根により日本人の顔貌に適合しや すいように改良, 開発されたもので, 図 4 のように鼻下 点指示桿, オトガイ底指示桿, 瞳孔線指示桿, 上下口唇 接合線指示桿および垂直桿より構成されている。

てのバイトゲージを用いて以下のものが計測できる。

1）鼻下点ーオトガイ底間距離（図6)

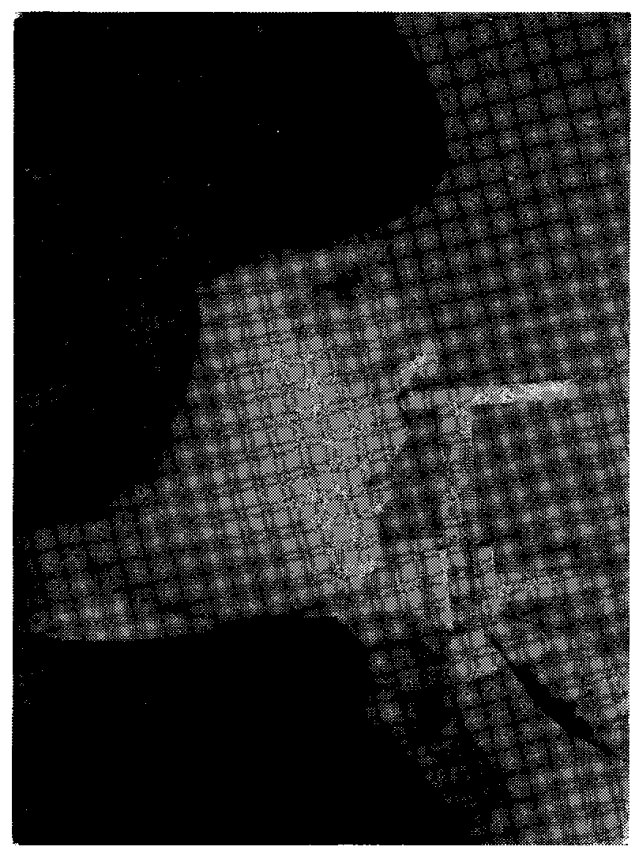

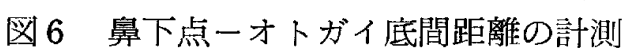

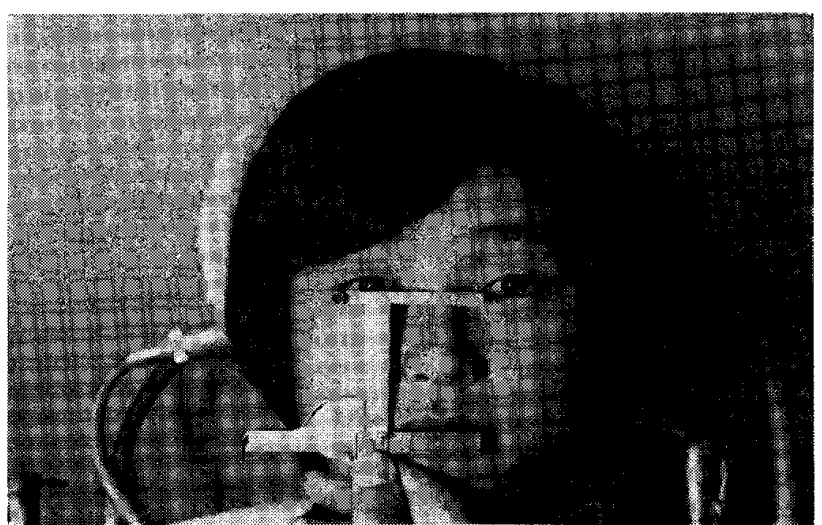

図 7 瞳孔線一上下曰唇接合線間距離の計測 
i ) 下顎安静位

ii) 中心咬合位。

(1) 有柬顎時の記録を利用する。

(2) 旧義歯の咬合高径が適当であれば利用する.

2 ) 瞳孔線一上下口唇接合線間距離（威 7 )

3 ) 左示指長 (図 8 )

図 9 は坪根式バイトゲージの 1 号機であり，オトガイ

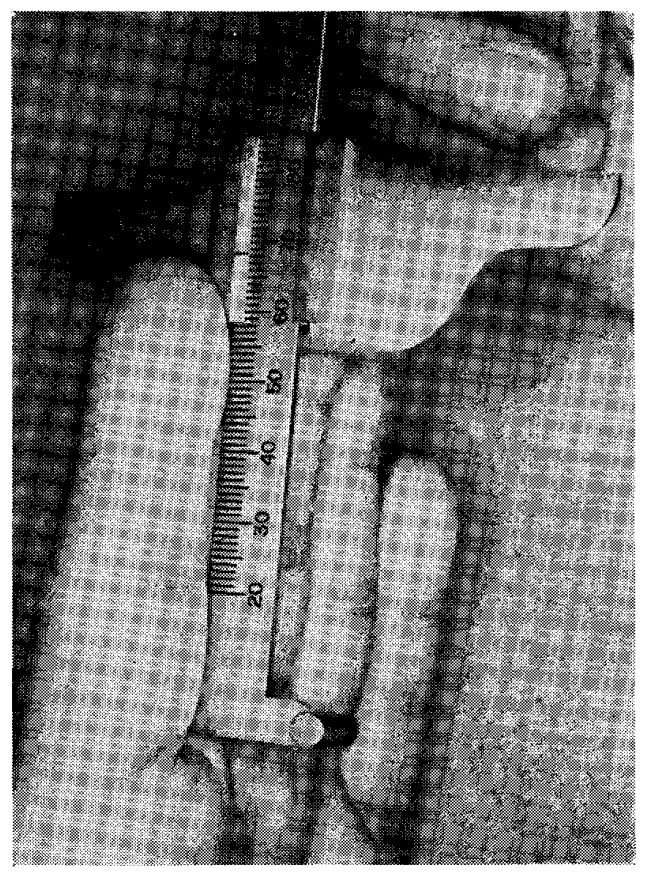

厚 8 左示指長の計測

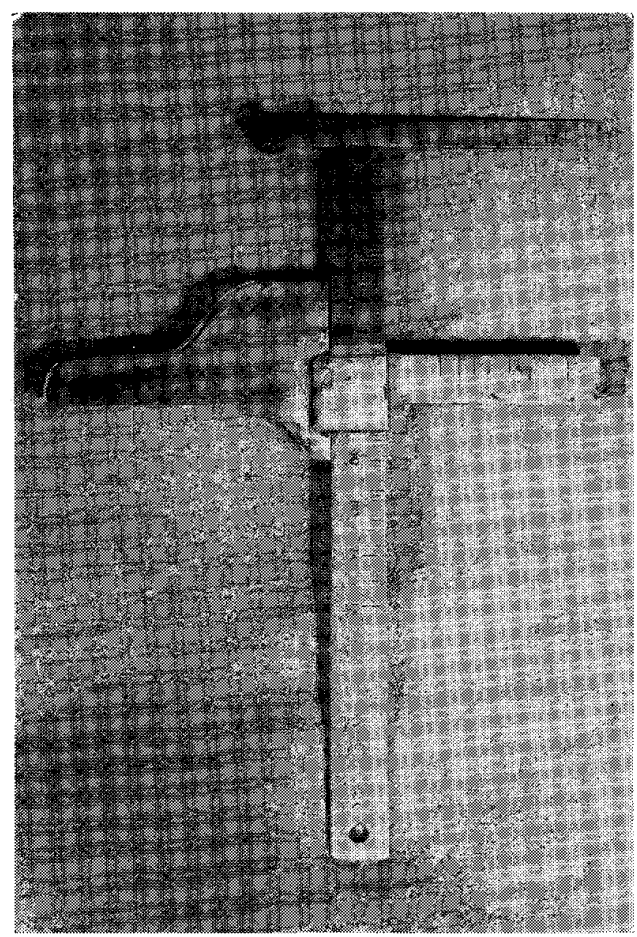

脑 9 坪根式バイトゲーシ 1 号機
底指示棉が幅 $5 \mathrm{~mm}$ の板状であったが，正中部が明示さ れにくいので，現在は1.5mmのものに改められており， またオトガイ底指示桿に突起をつけ左示指長を测定でき やすいようにしていたが，必要性が少ないので現在の型 となった（図 4)。乙のように種々の改良を加えながら 現在の型になったのであるが, 改良のおもな点と坪根式 バイトゲージの特徵を挙げると以下のようなるのであ る.

1) 鼻下点を指示しやすいように鼻下点指示桿の先端 を丸くしたと。

2）鼻下点指示桿およびオトガイ底指示桿が口唇部の 膨隆度に関係なく指示されるように垂植桿より䧻 したこと。

3) オトガイ底指示桿を幅 $1.5 \mathrm{~mm}$ とし，かつ丸みを 与えるととによってオトガイ底正中部に適合しや すくなったてと．

4) 瞳孔線指示桿と上下下唇接合線指示桿を利用する とノギスの代りとなり, 点描間計測法などに利用 できる．著者らは同部の先端を鋭くすることによ り多方面に利用している（図10）。

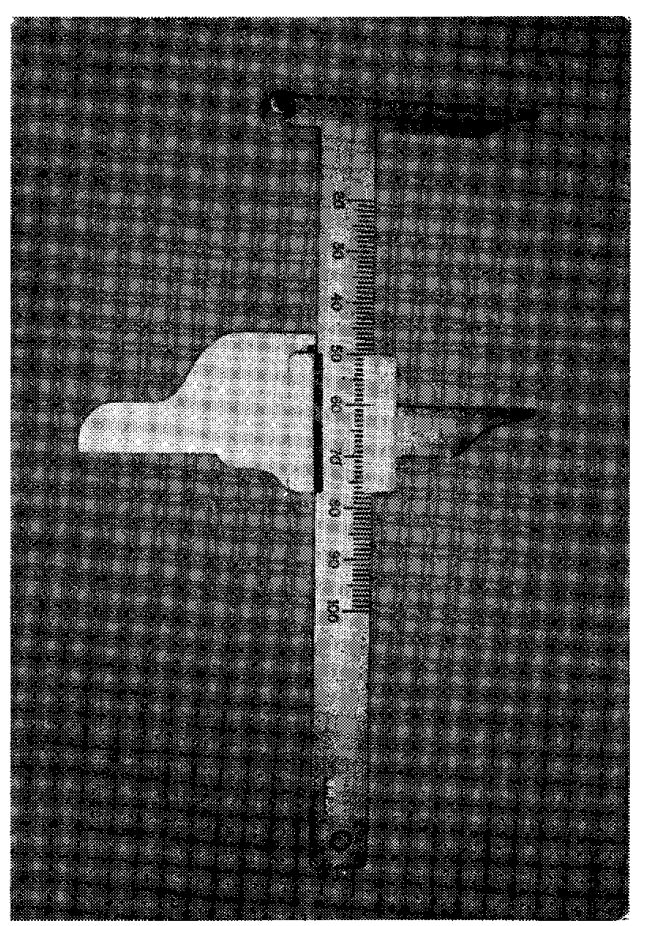

図10 曈孔線指示桿と上下口唇接合線指示桿の先端 を鋭くすることにより，点描間計測法に利用 しやすいように改良を加えた坪根式バイトゲ ージ. 
表 1 坪根式バイトゲージによる鼻下点ーオトガイ底間距離の測定結果

(単位 $\mathrm{mm}$ )

\begin{tabular}{l|c|c|c|c|c|c}
\hline \hline & & \multicolumn{3}{|c}{ 被 } & \multicolumn{2}{c}{ 験 } \\
\cline { 3 - 7 } \multicolumn{2}{c|}{} & $\mathrm{A}$ & $\mathrm{B}$ & $\mathrm{C}$ & $\mathrm{D}$ & $\mathrm{E}$ \\
\hline \multirow{3}{*}{ 測 } & 1 & $58.3 \pm 1.25$ & $61.2 \pm 1.52$ & $68.3 \pm 0.89$ & $56.7 \pm 1.15$ & $62.9 \pm 0.93$ \\
定 & 2 & $60.2 \pm 1.35$ & $63.0 \pm 1.27$ & $67.4 \pm 1.38$ & $58.5 \pm 0.72$ & $63.7 \pm 0.91$ \\
者 & 3 & $59.2 \pm 0.74$ & $59.6 \pm 1.26$ & $69.3 \pm 0.89$ & $56.8 \pm 0.44$ & $63.9 \pm 1.50$ \\
& 4 & $59.4 \pm 0.82$ & $62.8 \pm 1.59$ & $69.7 \pm 0.87$ & $58.8 \pm 0.83$ & $64.5 \pm 0.69$ \\
& 5 & $58.5 \pm 0.37$ & $60.7 \pm 1.35$ & $66.7 \pm 0.65$ & $56.8 \pm 0.45$ & $64.0 \pm 1.19$ \\
\hline
\end{tabular}

\section{計測值の個人特性について}

鼻下点ーオトガイ底間距崔計測法は軟組織間距離を計 測するものであるから，圧接状態，鼻下点およびオトガ イ底部の適合状態，さらにバイトゲージをあてる角度に より変化が現われるととなどの欠点がある ${ }^{34)}$ 。

そこで圧接状態による差異, 測定者による差異さらに 個々の測定者の計測值のバラつきなどを検討するため に, 測定者 5 名（補緅学教室在籍 2 年以上）が正常有歯 頒者 5 名を被検者とし，鼻下点一オトガイ底間距離を計 測した。この時, 被検者に up-right position をと らせ，口唇を軽く閐し，軽く柬牙を接触させた咬合位に おける鼻下点一オトガイ底間距離を 5 回ずつ計測した。 表 1 はその結果である.

これより同一被検者に対する各測定者の計測值には有 意の差があるが，同一測定者間の個々の值についてみる とバラつきが小さいととがわかった。

すなわち，バイトゲージによる垂直的䫟関係の計測は 多田 ${ }^{34)}$ も述べているように，点描間計測法などと比較 してみても，圧接状馝などにより計測值のバラつきが大 きくなるのであるが，反面バイトゲージの計測值は抜霜 前の記録がそのまま利用できるなどの経時的再現性があ ること，標点を明示ずる必要がないとと，さらに垂直的 頱関係の変化に対する追従性がよいなどの利点がある。 ゆえに，測定者は圧接の程度を可及的に同じ状態にし計 測する必要があり，またこうすることにより顔面棓測法 もかなり信頼性のある計測手段となりうることがわかっ た.

\section{被検者および計測法}

I 被 検 者

被検者は九州崡科大学男子学生（23歳～29歳, 平均 26.7 歳) 116名之同衛生学院女子学生（18歳～24歳, 平 均19.8歳）30名とした。
III計測方法おうよび計測部位

今回計測を行ったのは以下の部分である。

1）鼻下点一オトガイ底間距離（安静時）

2）鼻下点一オトガイ底間距離（咬合時）

3. 瞳孔線一上下口唇接合線間距離

4) 左示指長 (中手骨, 基節骨関節部から先端部まで の距離)

5 ) 左手掌幅 (小指外転筋付着部之背側骨間筋付着部 との幅径)

これらのうち，1)〜4)については坪根式バイトゲー ジを用い，5)については $1 / 20 \mathrm{~mm}$ 副尺つきミットヨ製 ノギスを用いて計測を行った（図6〜8，図11）。

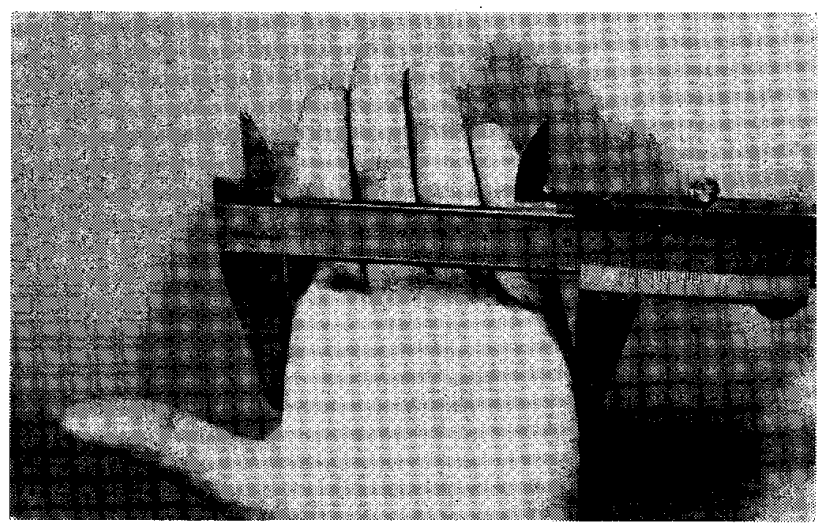

図11 ミットヨ製ノギスを用いた左手掌幅の計測

\section{結果および考察}

坪根式バイトゲージとノギスを用いて測定した鼻下点 一オトガイ底間距離（安静時, 咬合時), 瞳孔線一上下 口唇接合線間距離, 左示指長㧍よび左手掌幅の測定值は 正規分布をなしていた，そてでそれぞれについて平均值 および標準偏差を求めたところ表 2 のような結果を得 た。

安静時の 鼻下点一オトガイ 底間距晟は 男性が $69.5 \mathrm{~m}$ $\mathrm{m}$, 女性は64.6mm, 咬合㸝の鼻下点一オトガイ底間距 
表 2 鼻下点一オトガイ底間距離, 瞳孔一上下口唇接合線間距離, 左示指長および左手 掌幅の訫測值 (単位 $\mathrm{mm}$ )

\begin{tabular}{|c|c|c|}
\hline & 男 & 性 \\
\hline 鼻下点ーオトガイ底間距離（安静時） & $69.5 \pm 6.0$ & $64.6 \pm 3.9$ \\
\hline 鼻下点一オトガイ底間距離（咬合時） & $67 \cdot 0 \pm 6 \cdot 1$ & $62.7 \pm 3.8$ \\
\hline 瞳孔一上下口唇接合線閒距離 & $70.4 \pm 4.4$ & $66.4 \pm 3.4$ \\
\hline 左示指長 & $70 \cdot 2 \pm 5 \cdot 0$ & $66 \cdot 2 \pm 3.8$ \\
\hline 左手掌幅 & $\begin{array}{c}83.8 \pm 5.6 \\
(\mathrm{n}=116)\end{array}$ & $\begin{array}{l}72.2 \pm 3.1 \\
(\mathrm{n}=30)\end{array}$ \\
\hline
\end{tabular}

表 3 鼻下点一オトガイ底間距離と睲孔一上下口唇接合線間距離, 左示指長及び左手掌 幅との相関について（男性）

\begin{tabular}{|c|c|c|c|}
\hline & 瞳孔－上下口唇接合線間距離 & 左示指長 & 左手掌幅 \\
\hline $\begin{array}{l}\text { 䶊下点一オトガイ離 (安間 } \\
\text { 静時) }\end{array}$ & $\begin{array}{r}0.59 \\
* *\end{array}$ & $\begin{array}{r}0.49 \\
* *\end{array}$ & 0.09 \\
\hline $\begin{array}{l}\text { 䶊下点一オトガイ離 (閔 } \\
\text { 合時) }\end{array}$ & $\begin{array}{r}0.50 \\
* *\end{array}$ & 0.37 & 0.08 \\
\hline
\end{tabular}

**危険率 $0.1 \%$ で有意

第 4 鼻下点一オトガイ底間距離と瞳孔一上下口唇接合線間距離, 左示指長及び左手掌 幅との相関について（女性）

\begin{tabular}{|c|c|c|c|}
\hline & 瞳孔一上下曰唇接合線間距離 & 左示指長 & 左手掌幅 \\
\hline $\begin{array}{l}\text { 穓下点一オトガイ底間 } \\
\text { 距安静時) }\end{array}$ & $\begin{array}{r}0.65 \\
* * *\end{array}$ & $\begin{array}{r}0.54 \\
* *\end{array}$ & 0.18 \\
\hline 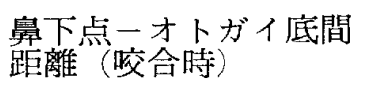 & 0.617 & 0.32 & 0.19 \\
\hline
\end{tabular}

**** 危険率 $0.1 \%$ で有意

離は男性が $67.0 \mathrm{~mm}$, 女性は $62.7 \mathrm{~mm}$, 瞳孔線一上下口 唇接合線間距離は男性が $70.4 \mathrm{~mm}$, 女性は $66.4 \mathrm{~mm}$, 左 示指長は男性が $70.2 \mathrm{~mm}$, 女性は $66.2 \mathrm{~mm}$, そして左手 掌幅は男性が $83.3 \mathrm{~mm}$ ，女性.は $72.2 \mathrm{~mm}$ であった。また 各部の相関については表 3 と 4 亿示す.

ここで舅下点ーオトガイ底間距離と関連があるといわ れている顔面あるいは身体各部との関係について整理す ると以下のようである。

1) Willis, F.M., Crawford, J.W. および McGee, G.F. の方法との比較

Willis, F.M. 15，161 は下枵安静位に打ける鼻下点一 オトガイ底間距離と瞳孔線一上下口唇接合線間距離が等 しいとして，Willisのバイトゲージで而者の距離を測定 することにより咬合高径を求めた(図12). またMcGee, G.F.17) も両者を比較してほ添等しいと述べている（図 13).

さらに Crawford, J.W. ${ }^{19}$ は Sorenson の

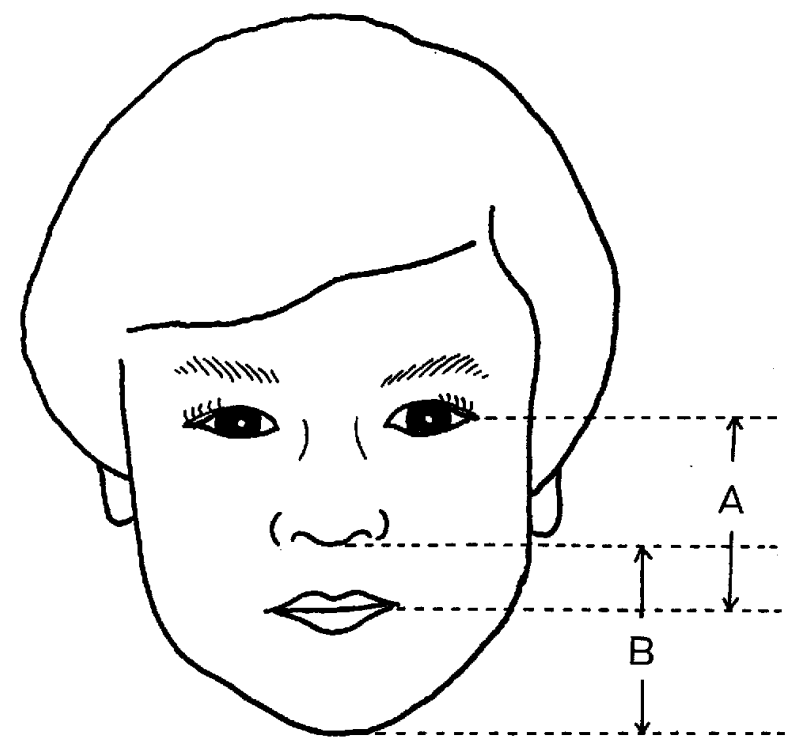

図12A Willis 法 $A=B$

$\mathrm{A}$ ：瞳孔線一上下口唇接合線間距離

B：鼻下点一オトガイ底間距離 


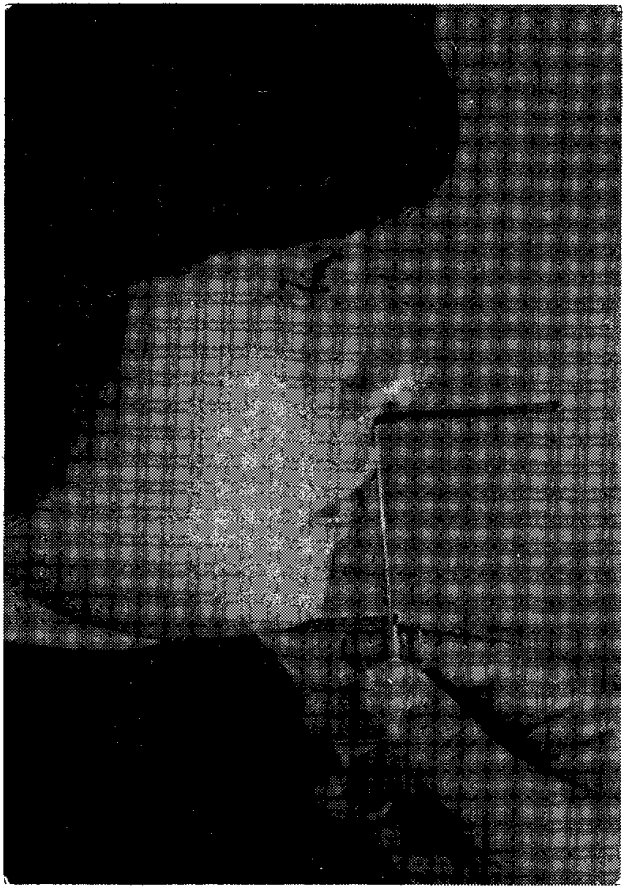

図12 B Willis のバイトゲージを用いた㑭下点一 オトガイ底間距離の計測．との際垂直桿が 上口唇と接触するので鼻下点への適合が難 かしい.

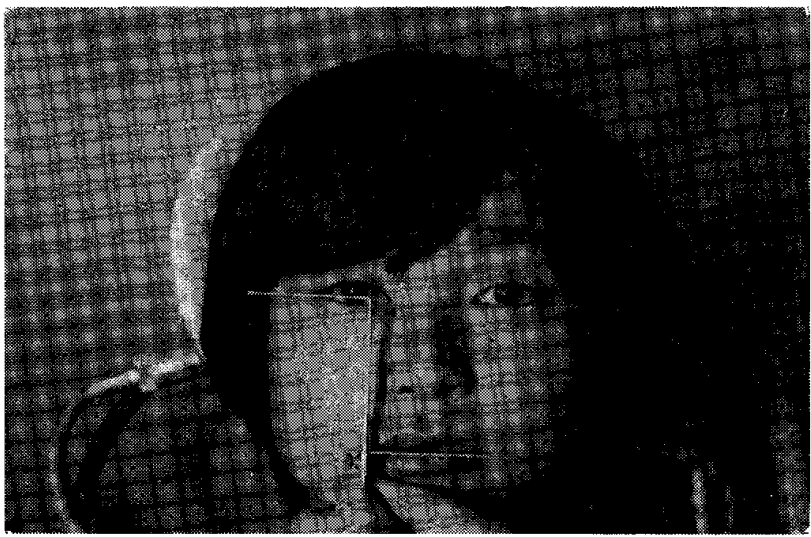

図12C Willis のバイトゲージを用いた瞳孔線一 上下曰唇接合線間距離の計測

dentofacial scale t用い，鼻根正中点一鼻下点間距 離と鼻下点一オトガイ底間距離を測定し，両者がほぼ等 しくなると述べている(図14）。しかし，鼻根正中点は その位置を客観的に明示できにくい久点があり，今回の 測定から除いた。

著者らの測定結果からみても鼻下点一オトガイ底閻距 離 (安静時) と瞳孔線一上下口唇接合線間距離はほほ 1 ：1の割合であった。

2) Bruno, A. ${ }^{20}$ の方法との比較

Bruno，A. は左手掌幅を測定し，鼻下点一オトガイ

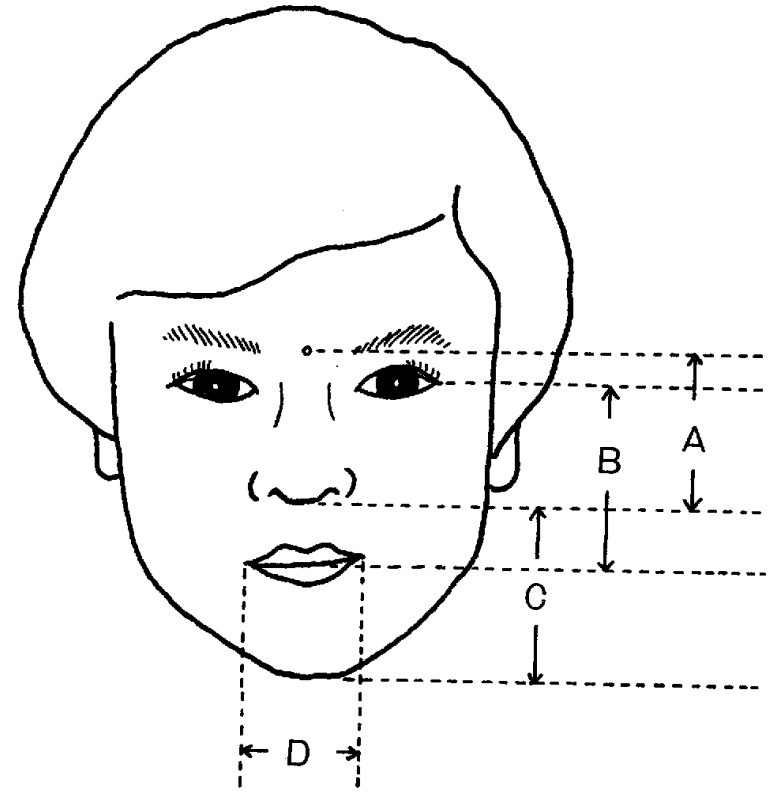

図13 Mc Gee 法 $A=B=C=D$

$\mathrm{A}$ ：眉間正中点一鼻下点䦭距離

$\mathrm{B}$ ：瞳孔線一上下口唇接合線間距離

$\mathrm{C}:$ 睤下点一オトガイ底間距離

$\mathrm{D}$ ：口角幅

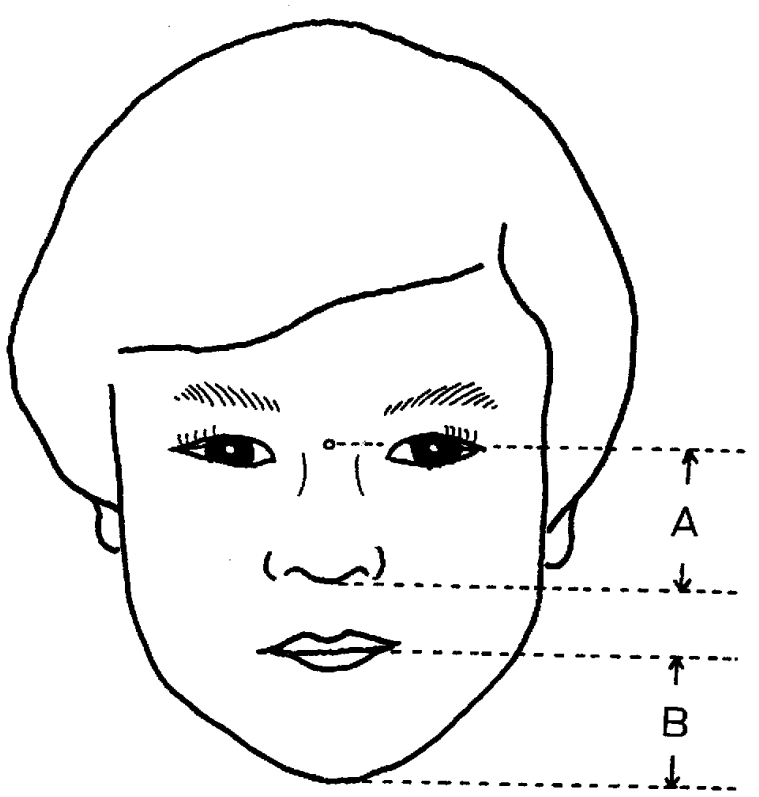

図14 Crawford 法 $\mathrm{A}=\mathrm{B}$

$\mathrm{A}$ ：鼻根正中点一鼻尖間距離

B : 上下口唇接合線一オトガイ底間距離

底間距離と等しいと述べている（図15）が，今回の測定 では，測定器具は異なるが，両者の差は平均值で男性 $14.3 \mathrm{~mm}$, 女性 $7.6 \mathrm{~mm}$ となり, かなり大きなものであ った. 

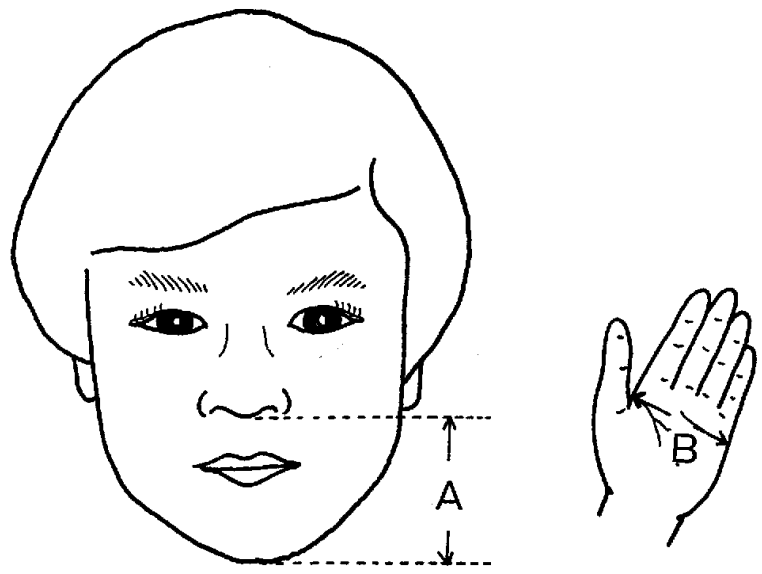

図15A Bruno 法 $\mathrm{A}=\mathrm{B}$

$\mathrm{A}$ ：鼻下点ーオトガイ底間距離

$B$ : 左手掌幅

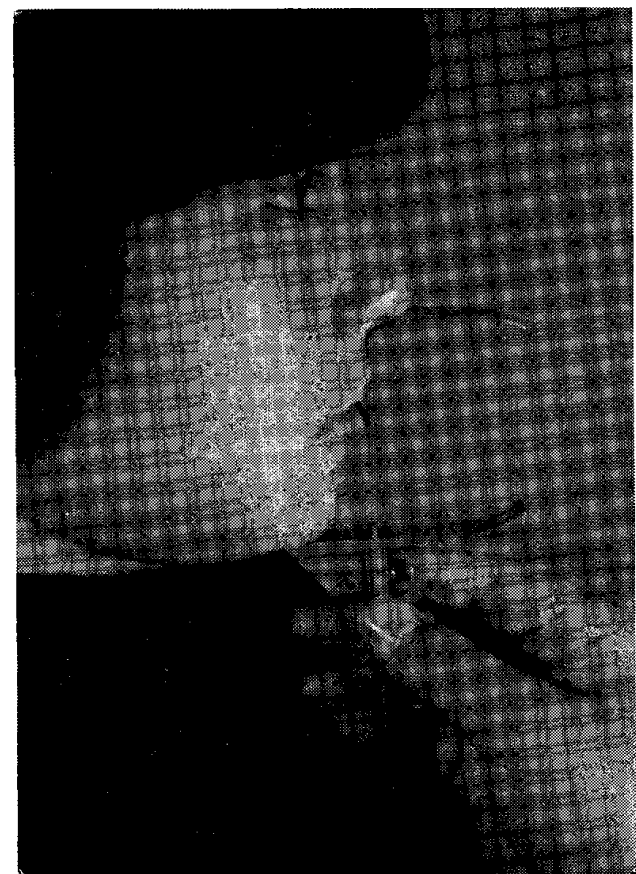

図15B Bruno のバイトゲージを用いた鼻下点一 オトガイ底間距離の計測. Willis法と同様 にロ唇部の膨隆がバイトゲージの適合をさ またげる。

\section{3 ）坪根の方法との比較}

坪根 2-24) は鼻下点一オトガイ底間距離 (安静時), 瞳孔線一上下口唇接合線間距離および左示指長が等しい と述べている（図 $6 \sim 8 ， 16$ ). 今回の測定では 3 者は ほぼ1：1：1の関係にあり，無菌顎の垂直的頻関係の 決定および確認の一基準となると思われる。

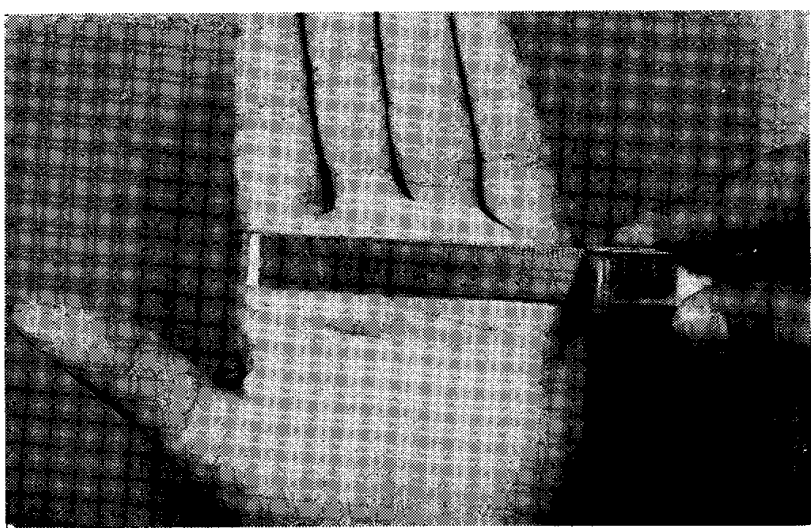

図15C Bruno バイトゲージを用いた左手掌幅の 計測
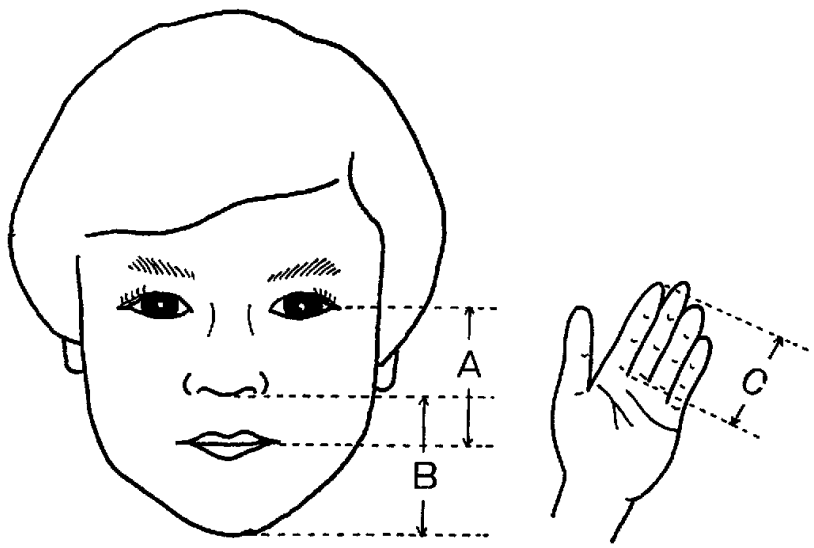

図16 坪根法 $\mathrm{A}=\mathrm{B}=\mathrm{C}$
$\mathrm{A}$ ：瞳孔線一上下口唇接合線間距離
$\mathrm{B}$ ：鼻下点一オトガイ底間距離
$\mathrm{C}:$ 左示指長

\section{ま と め}

総義歯製作時の垂直的㖽関係の決定および確認は非常 に難しい問題である．近年，乙の問題の解決法として電 気的・X線的などの科学的な方法が行われているにもか かわらず，臨床においてはバイトゲージ法や点描間計測 法などの比較的簡単な器具による計測法が主流を占めて おり，我々も坪根式バイトゲージを用い，臨床的にかな りの成績をあげている。

この坪根式バイトゲージは

1) 簡便で短時間で測定ができること.

2) 計測值が数值として表示できること.

3 ）計測値の経時的再現性があるとと.

4) 同一術者に於ては計測值にバラつきが少ないこ と.

$5 ）$ 日本人顔貌に適合しやすいとと。 
などの利点があるが，坪根式バイトゲージは軟組織を測 定するので圧接状態により計測值に誤差を生じやすいの で，患者に対し数回の計測を行い，その平均值をとる方 法が望ましい。
（稿を終わるにあたり，終始御慇篤な御指導と御校閲 を賜わった坪根政治名誉教授に感謝致します)

\section{引用 文 献}

1) Niswonger, M.E.: The rest position of the mandible and the centric relation, J. Am. Dent. Assoc. $21: 1572-1582,1934$.

2) Niswonger, M.E. : Obtaining the vertical relation in edentulous cases that existed prior to extraction, J. Am. Dent. Assoc. 25:1842-1847, 1938.

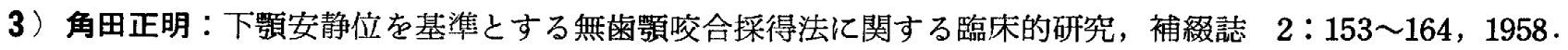

4 ）矢崎正方：艾合高径と freeway space, 日本歯科評論 $171: 15-21,1957$.

5 ) Pound, E. : Recapturing esthetic tooth position in edentulous patient, J. Am. Dent. Assoc. $55: 181-191,1957$.

6) Silverman, M. M. : Pre-extraction records to avoid premature aging of the denture patient, J. Prosthet. Dent. 5: 465-476, 1955.

7 ) Shanahan, T. E. J. : Physiologic vertical dimension and centric relation, J. Prosthet. Dent. $6: 741-747,1956$.

8 Booth, R.H. : Centric and functional bite relations, J. Am. Dent. Assoc. 30:262-266, 1943.

9) Booth, R.H. : Physiologic denture technique, J. Prosthet. Dent. 6:726-740, 1956.

10）河村洋二郎：歯科領域における筋電図の応用，歯界展望 $11 ： 225-230 ， 259-264,1954$.

11) Jankelson, B. : Physiology of human dental occlusion, J. Am. Dent. Assoc. 50:664680,1955 .

12) Stolze, K., Brill, N., et al. : The linear model, a statistical tool applied to psycophysical research in dental prosthetics, J. Oral Rehabilitation 3:395-402, 1976.

13) Tryde, G., Brill, N., et al. : Short-term changes in the perception of comfortable mandibular occlusal positions, J. Oral Rehabilitation $4: 17-21,1977$.

14) Tryde, G., Brill, N., et al.: Long-term changes in the perception of comfortable mandibular occlusal positions, J. Oral Rehabilitation 4:9-15, 1977.

15) Willis, F.M.: Esthetics of full denture construction, J. Am. Dent. Assoc. $17: 636-642$, 1930 .

16) Willis, F.M. : Feature of the face involved in full denture prosthesis, Dental Cosmos $77: 851-854,1935$.

17) McGee, G.F.: Use of the facial measurements in determining vertical dimension, J. Am. Dent. Assoc. $35: 342-350,1947$.

18) Wright, W.H. : Use of intra-oral jaw relation wax records in complete denture prosthesis, J. Am. Dent. Assoc. 26:542-557, 1939.

19) Crawford, J.W. : Restoration of lost facial dimension and facial harmony, J. Am. Dent. Assoc. $21: 664-671,1934$.

20) Bruno, A. : Importance of chewing height in prosthesis, Dental Digest $60: 544-555,1954$.

21）山田敏郎：無菌頢者の中心咬合の高さの決定に関する研究補遺, 補綴誌 $5: 35-51,1961$.

22）坪根政治：総義歯患者の咬合採得法, 医茵薬出版, 東京, 1958, 22-58. 
23）坪根政治：総義䨑の臨床効果に関する要点について，而至化学工業，東京，1962，19-42.

24）坪根政治・豊田静夫：総義崡臨床形態学, 医歯薬出版, 東京, 1978, 151-171.

25）堀江銈一：堀江式総義菡調整法，森村歯科商会，東京，1973，131-145.

26) Jordan, L.G. : Immeadiate denture, J. Am. Dent. Assoc. 25:868-884, 1938.

27) Jordan, L.G.: Cooperation of oral surgeon and prosthodontist in rendering artificial denture service, J. Prosthet. Dent. 2:55-59, 1952.

28) Swenson, M.G.: Complete denture, 4 th ed., C. V. Mosby Co., St. Louis, 1959, 112-138.

29) Atwood, D. A. : A cephalometric study of the clinical rest position of mandible. Part 1, J. Prosthet. Dent. 6:504-519, 1956.

30) Atwood, D.A. : A cephalometric study of the clinical rest position of mandible. Part 2, J. Prosthet. Dent. $7: 544-552,1957$.

31) Atwood, D.A. : A cephalometric study of the clinical rest position of mandible. Part 3, J. Prosthet. Dent. 8:698-708, 1958.

32）松本 正：頭部X線規格写真計測法の補綴学の忍用に関する研究，補綴誌 $15: 209-220,1971$.

33）早川 蔽：頭部 $X$ 線規格写真計測法による咬合高径の研究, 補綴誌 $20: 186-191,1976$.

34）多田集一：影間距離計測における基準点設定法の改善に関する実験的研究, 歯科学報 $75: 1-19,1975$. 